\title{
Simultaneous monitoring of SARS-CoV-2, bacteria, and fungi in indoor air of hospital: a study on Hajar Hospital in Shahrekord, Iran
}

\author{
Sara Hemati ${ }^{1}$ - Gholam Reza Mobini ${ }^{2}$. Mohsen Heidari ${ }^{3}$ - Fereidoun Rahmani ${ }^{4}$ - Akbar Soleymani Babadi $^{5}$. \\ Marzieh Farhadkhani ${ }^{6}$. Heshmatollah Nourmoradi ${ }^{7,8}$ - Ahmad Raeisi ${ }^{9}$. Ali Ahmadi ${ }^{10}$. Abbas Khodabakhshi ${ }^{1}$. \\ Mehraban Sadeghi ${ }^{1} \cdot$ Milad Bagheri $^{1} \cdot$ Majid Validi $^{11} \cdot$ Simin Taghipour ${ }^{12} \cdot$ Fazel Mohammadi-Moghadam $^{1}$
}

Received: 25 November 2020 / Accepted: 22 March 2021 / Published online: 10 April 2021

(C) The Author(s), under exclusive licence to Springer-Verlag GmbH Germany, part of Springer Nature 2021

\begin{abstract}
The novel SARS-CoV-2 outbreak was declared as pandemic by the World Health Organization (WHO) on March 11, 2020. Understanding the airborne route of SARS-CoV-2 transmission is essential for infection prevention and control. In this study, a total of 107 indoor air samples (45 SARS-CoV-2, 62 bacteria, and fungi) were collected from different wards of the Hajar Hospital in Shahrekord, Iran. Simultaneously, bacterial and fungal samples were also collected from the ambient air of hospital yard. Overall, 6 positive air samples were detected in the infectious 1 and infectious 2 wards, intensive care unit (ICU), computed tomography (CT) scan, respiratory patients' clinic, and personal protective equipment (PPE) room. Also, airborne bacteria and fungi were simultaneously detected in the various wards of the hospital with concentrations ranging from 14 to $106 \mathrm{CFU} \mathrm{m}{ }^{-3}$ and 18 to $141 \mathrm{CFU} \mathrm{m}^{-3}$, respectively. The highest mean concentrations of bacteria and fungi were observed in respiratory patients' clinics and ICU wards, respectively. Significant correlation $(p<0.05)$ was found between airborne bacterial concentration and the presence of SARS-CoV-2, while no significant correlation was found between fungi concentration and the virus presence. This study provided an additional evidence about the presence of SARS-CoV-2 in the indoor air of a hospital that admitted COVID-19 patients. Moreover, it was revealed that the monitoring of microbial quality of indoor air in such hospitals is very important, especially during the COVID-19 pandemic, for controlling the nosocomial infections.
\end{abstract}

Keywords COVID-19 pandemic $\cdot$ SARS-CoV-2 $\cdot$ Airborne route $\cdot$ Bacteria $\cdot$ Fungi

\section{Introduction}

Hospitals have a relatively high airborne microbial concentration including bacteria, fungi, and viruses that may spread respiratory infections, especially for sensitive individuals

\section{Highlights}

-SARS-CoV-2 was detected in 4-h sampling runs.

-The association between airborne bacterial and fungal concentrations and SARS-CoV-2 was obtained for the first time.

-SARS-CoV-2 was detected in $2 \mathrm{~m}$ distance to the patient's bed.

-Significant correlation was found between airborne bacteria concentration and the virus.

- The presence of airborne bacteria and fungi may be an additional threat for COVID-19 patients.

Responsible Editor: Lotfi Aleya

Fazel Mohammadi-Moghadam

fm.moghadam@skums.ac.ir

Extended author information available on the last page of the article
(He et al. 2020; Wu et al. 2020). Respiratory infections are the leading cause of epidemics, causing about 5 million death per year in the world (Zumla and Niederman 2020). COVID19 was first diagnosed in Wuhan, Hubei Province, China, in December 2019 (Forrester et al. 2020). This infection (novel coronavirus, severe acute respiratory syndrome coronavirus 2 named SARS-CoV-2) has spread to many countries around the world and has become a severe threat globally (Holshue et al. 2020; Ricco et al. 2020).

On March 11, 2020, World Health Organization (WHO) declared this respiratory infection outbreak as a pandemic, indicating a significant global conflict with the disease (WHO 2020). On February 19, 2020, the first case was reported in Iran (Faridi et al. 2020). Until November 24, 2020, a total of 880,542 confirmed cases and 45,738 deaths were reported in Iran (https://www.worldometers. info/coronavirus/\# countries).

In order to prevent further spread of COVID-19, it is necessary to identify and control all SARS-CoV-2 transmission 
routes (Forrester et al. 2020). Based on previous studies, SARS-CoV-2 is transmitted through respiratory droplets and person to person contact (Wang et al. 2020a). The transmission of aerosols is possible when people are exposed to high concentrations of aerosols in indoor environments (Jayaweera et al. 2020; Razzini et al. 2020). Some droplets are directly emitted from COVID-19 patients during breathing, talking, sneezing, or coughing and become airborne (Jayaweera et al. 2020; Wang et al. 2020a). Small droplets exhaled by an infected person (even people without symptoms) can travel a distance of meters in the air, causing spread of COVID-19 (Repici et al. 2020). However, the maximum exact distance has not yet been determined (Morawska and Cao 2020). The potential of airborne transmission of SARS-CoV-2 is still being studied in the world (Buonanno et al. 2020; Morawska and Cao 2020). Airborne aerosols containing SARS-CoV-2 can spread in the environment through various activities related to health care, such as respiratory tract suctioning, intubation, bronchoscopy, and cardiopulmonary resuscitation (Cheung et al. 2020; Soma et al. 2020; Wong et al. 2020). Although the airborne transmission of SARS-CoV-2 is a pathway of COVID-19 contagion, more evidences are needed in this field (Buonanno et al. 2020; Morawska and Cao 2020; Setti et al. 2020). According to the studies, SARS-CoV-2 can survive in aerosols for hours and retain its infectious properties. Therefore, the transmission of SARS-CoV-2 through aerosols is possible (Chia et al. 2020; Tan et al. 2020; Yao et al. 2020). On the other hand, to our knowledge, no research has been previously carried out to evaluate the bacterial and fungal density in the indoor air of different wards of hospital during the COVID-19 pandemic. Therefore, the main objectives of this study were the following: (1) detecting the SARS-CoV-2 virus in indoor air, (2) investigating the effect of distance to the COVID-19 patients bed in the detection of SARS-CoV-2 virus in air samples, and (3) monitoring the concentration and diversity of bacterial and fungal bioaerosols in Hajar Hospital, Shahrekord, Iran, which is the highest altitude capital city of Iran.

\section{Materials and methods}

\section{Study area and sampling locations}

Hajar Hospital is an educational-therapeutic hospital in Shahrekord, Iran, with over 373 beds. To date, around 1850 patients with confirmed COVID-19 have been admitted to this hospital from 20th February 2020. Therefore, the indoor environment of this hospital may be contaminated with SARSCoV-2.

Air samples were collected in 10 days during a 2-week period from July 25 to August 10, 2020. Bioaerosol sampler set-up was placed in each ward to collect air samples. The samples were taken from the infectious ward 1 (suspect and positive), infectious ward 2 (positive), intensive care unit (ICU), pediatric ward, radiology, computed tomography (CT) scan, emergency ward, respiratory patients' clinic, laundry, toilet of COVID-19 patients, and personal protective equipment (PPE) rooms of staff. Figure 1 shows the location of indoor air samples collected from the different wards of the hospital. All air samples were taken in the presence of COVID-19 patients. During air sampling, $90 \%$ of the patients were equipped with face mask. However, they removed the masks during talking with the phone and eating. Moreover, $98 \%$ of the patients had one companion in infectious 1 and infectious 2 wards.

\section{Sampling methods}

A total of 45 and 62 air samples were taken from different wards of the hospital for SARS-CoV-2 detection and airborne bacterial/fungal monitoring, respectively. Also, during the study, bacterial and fungal samples were collected from the hospital yard to compare with indoor air samples. The air samples for virus detection in each ward were collected using the standard midget impinger (SKC. Inc., England) containing 20-mL viral transport medium (VTM) at flow rate of $2 \mathrm{~L}$ $\min ^{-1}$ for $4 \mathrm{~h}$ (480 L) (Faridi et al. 2020). Simultaneously, the sampling of airborne bacterial and fungal bioaerosols was also carried out using a single-stage Andersen sampler (Model EP_120V, SKC, Taiwan). The flow rate of the pump was $28.3 \mathrm{~L} \mathrm{~min}^{-1}$ during $5 \mathrm{~min}$ and $2 \mathrm{~min}$ for bacterial and fungal samples, respectively. Tryptic soy agar (TSA) and Sabouraud dextrose agar (SDA) culture media were used for bacterial and fungal sampling, respectively (Fabian et al. 2005; Zhong et al. 2016). The indoor air sampler was located at a height of about $1.5 \mathrm{~m}$ from the floor. Based on the protocol of the Centers for Disease Control and Prevention (CDC) (May 13, CDC 2020), prior to each sampling, the impingers were autoclaved and other accessories were disinfected with alcohol solution $70 \%$. The environmental parameters such as temperature, relative humidity, and ventilation rate were recorded at the beginning and the end of the sampling process. Finally, all the collected samples were stored in a cool box (4 ${ }^{\circ} \mathrm{C}$ ) and immediately transported to the laboratory.

\section{Quantitative real-time PCR assays}

Laboratory confirmation of the SARS-CoV-2 in the indoor air samples was performed using real-time reverse transcription polymerase chain reaction (RT-PCR). In this regard, RNA was extracted using the RNJia Virus Kit (RojeTechnologies, Yazd, Iran) according to the manufacturer's protocol. Briefly, $140 \mu \mathrm{L}$ of each sample was mixed with $560-\mu \mathrm{L}$ lysis buffer. After appropriate incubation, binding buffer was added and the mixture was loaded on the silica 


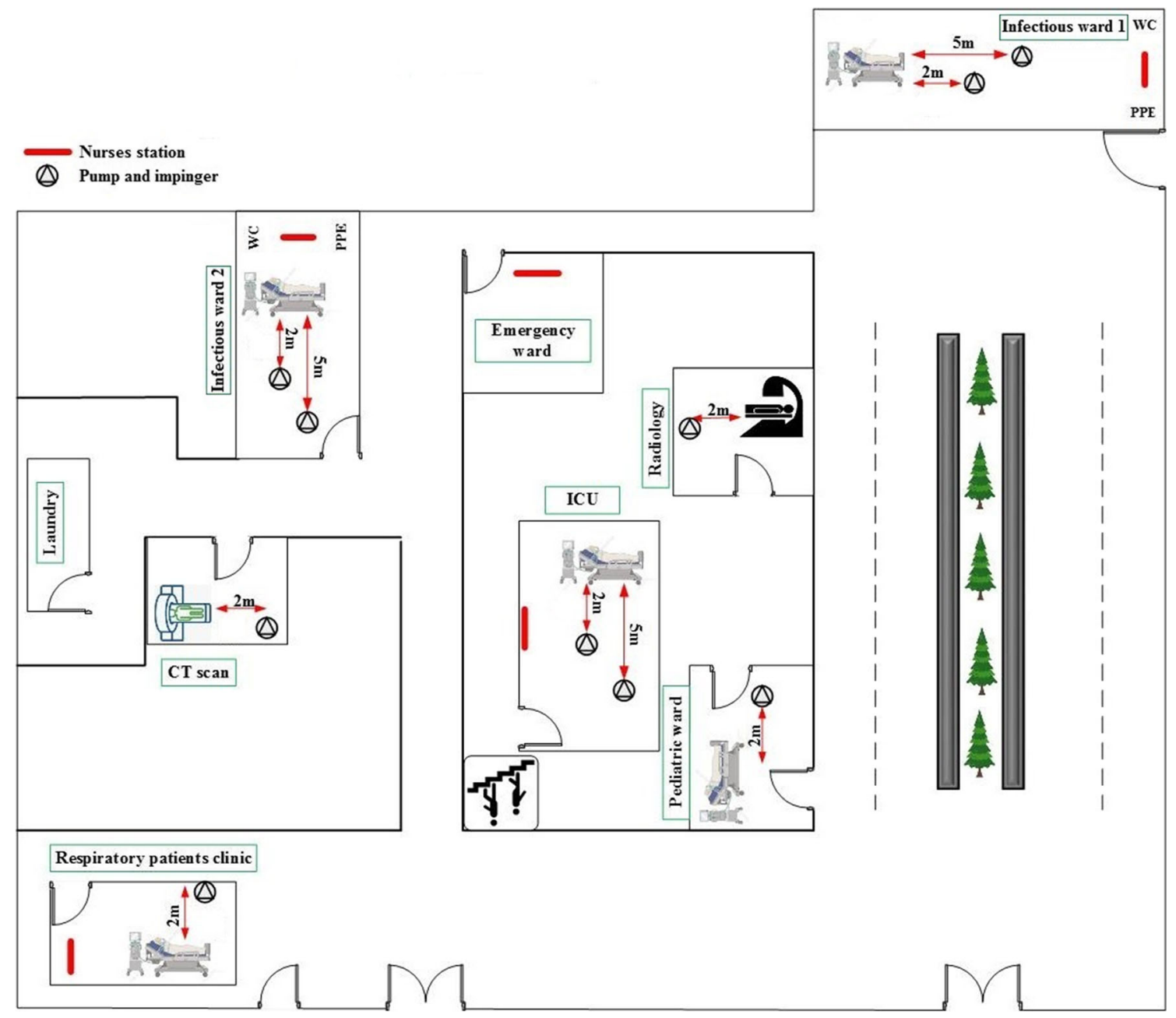

Fig. 1 The locations of indoor air samples in the different wards of hospital

column. High pure viral RNA was eluted from the column after washing steps. Real-time PCR was conducted for SARS-CoV-2 RNA-dependent RNA polymerase (RDRP) on the FAM Channel and the nucleocapsid protein (NP) on the HEX Channel using the Novel Coronavirus (2019-nCoV) Nucleic Acid Diagnostic Kit (Pishtazteb Zaman Diagnostics, Tehran, Iran). RNase P gene was considered for RNA extraction quality control on the ROX channel. Each reaction mixture was prepared from $4 \mu \mathrm{L}$ of the PCR master mix, $0.5 \mu \mathrm{L}$ of RT enzyme, $5 \mu \mathrm{L}$ of primer and probe mixture, $5 \mu \mathrm{L}$ of RNA template, and $5.5 \mu \mathrm{L}$ of water. The real-time PCR was performed using Rotor-Gene-Q instrument (Qiagen, Germany). Amplification cycling was optimized on $50^{\circ} \mathrm{C}$ for $20 \mathrm{~min}, 95$ ${ }^{\circ} \mathrm{C}$ for $4 \mathrm{~min}$, followed by 45 cycles of $94{ }^{\circ} \mathrm{C}$ for $10 \mathrm{~s}$ and 55 ${ }^{\circ} \mathrm{C}$ for $40 \mathrm{~s}$. A positive control and a negative control were considered for all assays. Any tubes with sharp amplification curves in the logarithmic phase of both target genes (RDRP and NP) were considered as positive infected samples to COVID-19. Otherwise, the data was invalid, and the experiment should be repeated. All samples were analyzed in duplicate.

\section{Identification of bacterial and fungal bioaerosols}

To detect bacterial content, the plates of TSA culture media were incubated for $48-72 \mathrm{~h}$ at $35-37^{\circ} \mathrm{C}$. Also, SDA plates were placed at $20-28^{\circ} \mathrm{C}$ (laboratory temperature) for 3-5 days (Sautour et al. 2009; Hamad and Soliman 2020; Dehghani et al. 2018). Following the enumeration of the number of colonies, the concentration of bacterial and fungal bioaerosols in the air samples was expressed as $\mathrm{CFU} \mathrm{m} \mathrm{m}^{-3}$. The bacterial genera were identified by Gram staining and biochemical tests (catalase, oxidase, coagulase, oxidation/fermentation (OF), and MR/VP). The fungal samples were observed using a fluorescence microscope at $100 \times$ to $400 \times$ magnification.

\section{Statistical analysis}

Descriptive statistics of the variables were presented as minimum, maximum, mean, and standard deviation $( \pm \mathrm{SD})$. The normality of data distribution was checked by KolmogorovSmirnov test. The comparisons between groups were performed with analysis of parametric test. One-way ANOVA 
was used to analyze the statistical difference of airborne bacterial and fungal concentrations among different wards of the hospital. An independent sample $t$ test was applied for correlating the airborne bacterial and fungal concentrations with SARS-CoV-2. $p<0.05$ was considered statistically significant. Statistical analysis was performed using IBM SPSS statistics software, version 23 .

\section{Results}

\section{SARS-CoV-2 detection}

Airborne bioaerosol sampling was conducted in different wards of Hajar Hospital in Shahrekord, Iran. All COVID-19 patients had severe respiratory and gastrointestinal symptoms at the time of sampling. Specifications of all indoor air samples for SARS-CoV-2 detection are shown in Table 1. The study showed that, among all 45 collected indoor air samples, 6 samples were positive for the presence of SARS-CoV-2.

Also, the additional air sampling condition information are presented in Table S1.

\section{Diversity of airborne bioaerosol concentration}

The descriptive statistics of airborne bacterial and fungal bioaerosols are presented in Table 2. As seen, the highest mean concentrations of bacteria $\left(88 \mathrm{CFU} \mathrm{m}^{-3}\right)$ and fungi $\left(77 \mathrm{CFU} \mathrm{\textrm {m } ^ { - 3 }}\right.$ ) were observed at respiratory patients clinic and ICU, respectively.

One-way ANOVA results showed that there was no significant variation $(p>0.05)$ in the view of airborne bacterial and fungal concentration levels among the different wards of the hospital.

On the other hand, $t$ test analysis showed that in each ward, the SARS-CoV-2 samples were positive $(n=6)$, the mean bacterial concentration $\left(65 \mathrm{CFU} \mathrm{m}^{-3}\right)$ was higher than the other wards with negative result for SARS-CoV-2 $(n=25)$. Also, significant correlation $(p<0.05)$ was observed between the airborne bacterial concentration and the presence of SARS-CoV-2 in different wards. But it was not applicable to the fungi concentration.

The results showed that airborne Gram-negative bacilli and Gram-positive cocci were the most detected bacterial genera in the air of the hospital wards. However, Gram-negative bacilli were detected at higher frequency $(75 \%)$ in the air of the ICU ward. As Fig. 2 shows, the most predominant bacteria were a genus of Staphylococcus, Bacillus, and Pseudomonas. Also, the most prevalent fungi genera in all the surveyed wards were Cladosporium spp. followed by Alternaria spp., Penicillium spp., and Yeast ssp. But Aspergillus spp. were only found in the ICU ward. As well as, the average concentration of airborne bacterial bioaerosols in the hospital yard $\left(39 \pm 5 \mathrm{CFU} \mathrm{m}^{-3}\right)$ was lower than that in the infectious wards, respiratory patients' clinic, and emergency ward, but it was more than the other wards. In addition, the average concentration of fungal bioaerosols in the hospital yard $(115 \pm 62 \mathrm{CFU}$ $\mathrm{m}^{-3}$ ) was higher than that in all of the indoor air samples. Moreover, Staphylococcus epidermidis, Acinetobacter, Pseudomonas, Enterobacter aerogenes, Proteus, Staphylococcus aureus, Micrococcus, Neisseria, Streptococcus bacteria and the Scopulariopsis, Mycelium, and Mucor fungi genera were just found in the indoor air of the hospital wards.

\section{Discussion}

\section{Detection of SARS-CoV-2}

The COVID-19 outbreak and rapid transmission of extreme deadly virus SARS-CoV-2 have affected the whole world. Airborne transmission of SARS-CoV-2 is still controversial, and the overall evidence for SARS-CoV-2 airborne transmission has become a global challenge. Hence, in the present study, indoor air samples were collected from the various wards of Hajar Hospital, Shahrekord (Iran) to determine the potential of airborne transmission of SARS-CoV-2.

Of the 45 samples collected in this study, 6 samples $(13.33 \%)$ had positive RT-PCR results for SARS-CoV-2. Five positive air samples were detected $2 \mathrm{~m}$ away from the patients' beds in infectious 1, infectious 2, ICU, CT scan, and respiratory patients' clinic wards. Also, one sample was positive in the PPE room of the infectious 2 ward. However, no positive samples were detected in radiology, pediatrics, toilet of COVID-19 patients, and emergency wards. During the air sampling in pediatric ward, only one 7-year-old child with moderate respiratory symptoms was hospitalized. In the radiology ward, after visiting each COVID-19 patient, mechanical ventilation systems were turned on for $15 \mathrm{~min}$. All fans were on and all windows were opened during the air sampling of COVID-19 patients' toilets.

Patients admitted to the emergency ward had symptoms of COVID-19 disease and suspected in terms of SARS-CoV-2. After taking the diagnostic clinical test, the patients with severe respiratory symptoms were transferred to the infectious 2 ward. However, no positive air samples were found in this ward.

Also, no positive samples were found in the air of the laundry ward (special for COVID-19 patients). It is noteworthy that laundry ward was equipped with a mechanical ventilation system as well as natural ventilation.

As opposed to our study, in Faridi et al. (2020) study, all 10 air samples collected from ICU wards of Imam Khomeini Hospital complex, Tehran (Iran) were negative for SARS-CoV-2. Also, all air samples taken from 
Table 1 The SARS-CoV-2 detections in the indoor air of different wards of Hajar hospital

\begin{tabular}{|c|c|c|c|c|c|c|c|c|}
\hline Ward & Site & $\begin{array}{l}\text { \# of } \\
\text { samples }\end{array}$ & $\begin{array}{l}\text { Distance from the } \\
\text { patient bed }(\mathrm{m})\end{array}$ & \# of patient & $\begin{array}{l}\text { Respiratory } \\
\text { symptom }^{\mathrm{a}}\end{array}$ & $\begin{array}{l}\text { Type of } \\
\text { ventilation }\end{array}$ & PCR results & $\begin{array}{l}\text { \# of positive } \\
\text { samples }\end{array}$ \\
\hline \multirow[t]{5}{*}{ Infectious 1} & \multirow[t]{2}{*}{ Patients' rooms } & 3 & 2 & \multirow[t]{2}{*}{12} & \multirow[t]{2}{*}{ Yes } & \multirow[t]{2}{*}{ Natural } & Positive & 1 \\
\hline & & 4 & 5 & & & & Negative & 0 \\
\hline & PPE' rooms & 2 & Not applicable & Not applicable & Yes & Natural & Negative & 0 \\
\hline & Corridor & 2 & Not applicable & Not applicable & Yes & Natural & Negative & 0 \\
\hline & Toilet & 2 & Not applicable & Not applicable & Yes & Natural & Negative & 0 \\
\hline \multirow[t]{5}{*}{ Infectious 2} & Patients' rooms & 3 & 2 & \multirow[t]{2}{*}{14} & \multirow[t]{2}{*}{ Yes } & \multirow[t]{2}{*}{ Natural } & Positive & 1 \\
\hline & & 4 & 5 & & & & Negative & 0 \\
\hline & PPE' rooms & 2 & Not applicable & Not applicable & Yes & Natural & Positive & 1 \\
\hline & Corridor & 2 & Not applicable & Not applicable & Yes & Natural & Negative & 0 \\
\hline & Toilet & 2 & Not applicable & Not applicable & Yes & Natural & Negative & 0 \\
\hline \multirow[t]{2}{*}{ ICU } & & 3 & 2 & \multirow[t]{2}{*}{15} & \multirow[t]{2}{*}{ Yes } & \multirow[t]{2}{*}{ Mechanical } & Positive & 1 \\
\hline & & 3 & 5 & & & & Negative & 0 \\
\hline \multicolumn{2}{|l|}{ Pediatric } & 2 & 2 & 1 & Yes & Natural & Negative & 0 \\
\hline \multicolumn{2}{|l|}{ Radiology } & 2 & 2 & About 12 per day & Yes & Mechanical & Negative & 0 \\
\hline \multicolumn{2}{|l|}{ CT scan } & 2 & 2 & About 60 per day & Yes & Mechanical & Positive & 1 \\
\hline \multicolumn{2}{|l|}{ Emergency } & 2 & Not applicable & About 30 per day & Yes & Natural & Negative & 0 \\
\hline \multicolumn{2}{|l|}{$\begin{array}{l}\text { Respiratory patients } \\
\text { clinic }\end{array}$} & 3 & 2 & About 110 per day & Yes & Natural & Positive & 1 \\
\hline \multicolumn{2}{|l|}{ Laundry } & 2 & Not applicable & Not applicable & Not applicable & Mechanical & Negative & 0 \\
\hline \multicolumn{2}{|l|}{ Sum } & 45 & & & & & & 6 \\
\hline
\end{tabular}

${ }^{\text {a }}$ Sneeze or cough during sampling

infection isolation rooms of a hospital in Singapore were negative for SARS-CoV-2 (Ong et al. 2020). Additionally, our results are in contrast with the recently published report by WHO that reported the airborne transmission of SARS-CoV-2 is not the transmission route for the COVID-19 pandemic (WHO 2020).

Table 2 Descriptive statistics of airborne bacteria, fungi, and SARA-CoV-2 in the surveyed wards

\begin{tabular}{|c|c|c|c|c|c|c|c|c|c|}
\hline \multirow[t]{2}{*}{ Ward } & & \multicolumn{3}{|c|}{ Bacteria $\left(\mathrm{CFU} \mathrm{m} \mathrm{m}^{-3}\right)$} & \multirow[t]{2}{*}{$p$ value } & \multicolumn{3}{|c|}{ Fungi $\left(\mathrm{CFU} \mathrm{m}^{-3}\right)$} & \multirow[t]{2}{*}{$p$ value } \\
\hline & & Mean \pm SD & Max & Min & & Mean \pm SD & Max & Min & \\
\hline Infectious 1 & & $44 \pm 31$ & 106 & 14 & \multirow[t]{9}{*}{$0.273 *^{\mathrm{a}}$} & $44 \pm 30$ & 88 & 18 & \multirow[t]{9}{*}{$0.055^{* \mathrm{~b}}$} \\
\hline Infectious 2 & & $41 \pm 34$ & 99 & 14 & & $53 \pm 25$ & 106 & 35 & \\
\hline ICU & & $19 \pm 8$ & 28 & 14 & & $77 \pm 57$ & 141 & 35 & \\
\hline Pediatric ward & & $39 \pm 15$ & 49 & 28 & & $35 \pm 25$ & 53 & 18 & \\
\hline Radiology & & $39 \pm 5$ & 42 & 35 & & $44 \pm 12$ & 53 & 35 & \\
\hline CT scan & & $32 \pm 5$ & 35 & 28 & & $53 \pm 25$ & 71 & 35 & \\
\hline Emergency ward & & $60 \pm 5$ & 64 & 57 & & $27 \pm 12$ & 35 & 18 & \\
\hline Respiratory patients clinic & & $88 \pm 15$ & 99 & 78 & & $62 \pm 12$ & 71 & 53 & \\
\hline Laundry & & $25 \pm 5$ & 28 & 21 & & $62 \pm 37$ & 88 & 35 & \\
\hline \multirow[t]{2}{*}{ Presence of SARS-CoV-2 } & 6 positive & $65 \pm 37$ & 99 & 14 & \multirow[t]{2}{*}{$0.02 * * \mathrm{c}$} & $38 \pm 13$ & 53 & 18 & \multirow[t]{2}{*}{$0.24 * * \mathrm{~d}$} \\
\hline & 25 negative & $36 \pm 23$ & 106 & 14 & & $54 \pm 30$ & 141 & 18 & \\
\hline
\end{tabular}

*ANOVA, **t test

${ }^{\text {a }}$ The correlation of bacterial concentrations between the surveyed wards

${ }^{b}$ The correlation of fungal concentrations between the surveyed wards

${ }^{\mathrm{c}}$ The correlation of bacterial concentrations with presence of SARS-CoV-2

${ }^{d}$ The correlation of fungal concentrations with presence of SARS-CoV-2 
Fig. 2 a Relative abundance of the bacterial and $\mathbf{b}$ fungal bioaerosols in the different wards and yard of the hospital
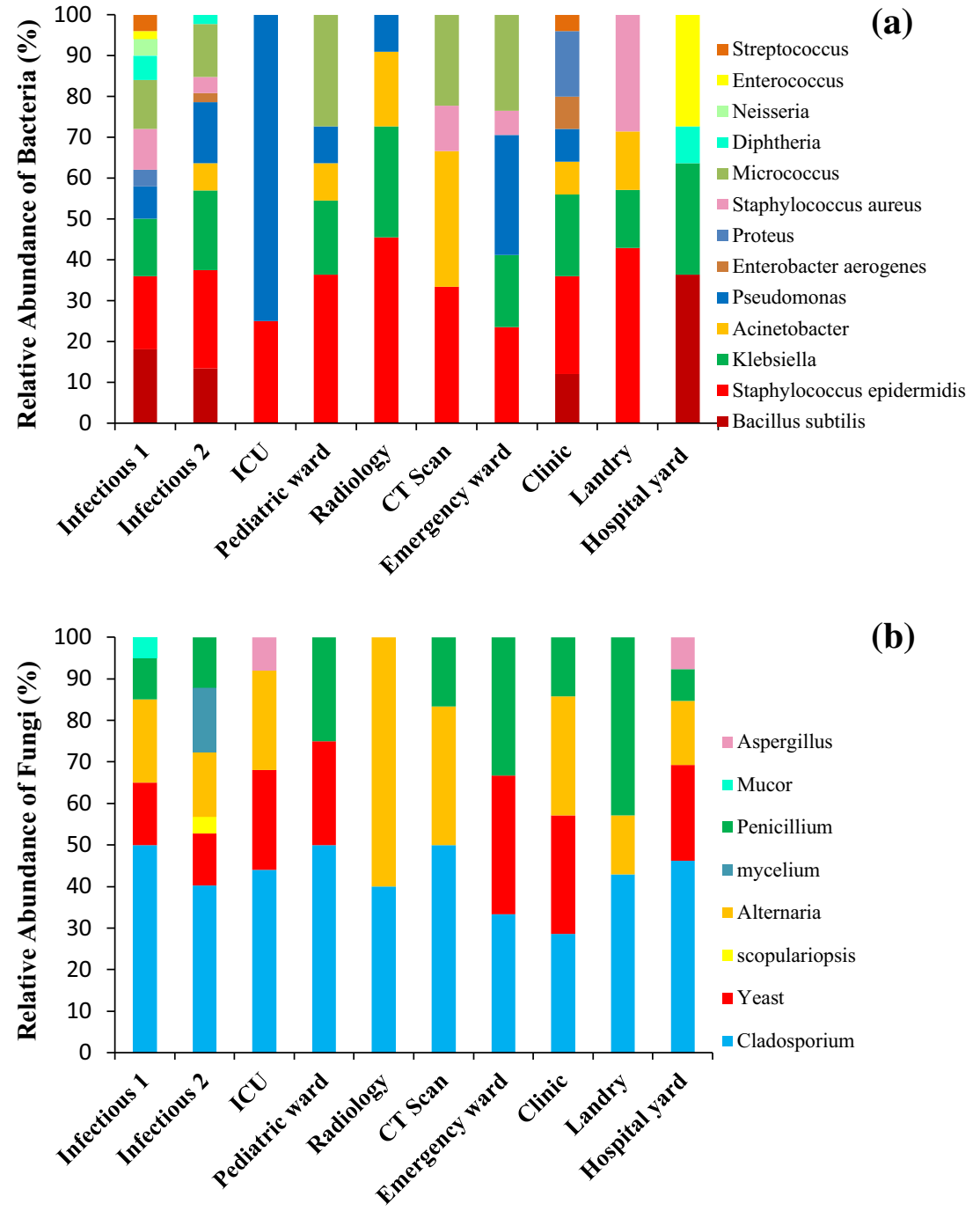

(b)
Recently, Kenarkoohi et al. (2020) study detected 2 positive air samples in the ICU ward at Shahid Mustafa Khomeini Hospital of Ilam, Iran. Their finding indicated that the airborne transmission of SARS-CoV-2 is possible and more stringent infection prevention and control (IPC) approaches should be considered in ICUs. The same report also highlighted the fact that the nosocomial transmission of SARS-CoV-2 aerosols in health-care facilities is possible (Jayaweera et al. 2020).

Also, Chia et al. (2020) detected SARS-CoV-2 PCRpositive particles in the air of ventilation equipped infection isolation rooms in the hospital general ward. However, they reported that airborne aerosols are not a key route of SARSCoV-2 transmission and to confirm the potential airborne transmission route of the virus, more data on infectiousness and viability are required.

Santarpia et al. (2020) reported that aerosol particles of SARS-CoV-2 can produce by respiration, toileting, and fomite contact. Also, air samples were positive for SARS-
CoV-2 at greater than distance of $2 \mathrm{~m}$ from patients and related hallways (Santarpia et al. 2020).

The hypothesis of the SARS-CoV-2 spreading up to more than $2 \mathrm{~m}$ away has been documented in recently published studies. If people wear face masks in all their daily activities, a distance of $2 \mathrm{~m}$ can be effective (Setti et al. 2020). Based on the recent studies and epidemiological observations, the SARS-CoV-2 virus can be transmitted via air up to $10 \mathrm{~m}$ from the emission sources especially in inadequately ventilated environments (Setti et al. 2020). Moreover, Guo et al. (2020) detected the SARS-CoV-2 aerosols at near air outlets $(35.7 \%)$, in patients' rooms $(44.4 \%)$, and in the doctors' offices $(12.5 \%)$. Their findings indicated that SARS-CoV-2 aerosols were distributed in the air and the maximum transmission distance of SARS-CoV-2 aerosol was found to be 4 $\mathrm{m}$.

On the other hand, Judson and Munster (2019) expressed the 'airborne transmission' to describe the disease spread by small droplet aerosols and droplet nuclei. This definition can 
be applied for the transmission of COVID-19 (Judson and Munster 2019). In this regard, Bourouiba (2020) study reported that small droplets are probably transferred to the distance of 7-8 $\mathrm{m}$ during sneezing. In addition, Lee et al. (2019) reported that larger droplets and finer aerosols can travel up to 2 and $6 \mathrm{~m}$, respectively. However, it should be noted that travel distance is affected by suspension time and size of droplets, air change rate, and the condition of ward vent openings (Nissen et al. 2020). But, in our study, no positive sample was found at a distance of $5 \mathrm{~m}$ from the COVID-19 patients' bed. Moreover, more extensive distancing measures (distance among persons up to $10 \mathrm{~m}$ ) should be performed inside indoor environments when face masks are not used. In the case of the common use of face masks, the distance among persons can be reduced to $2 \mathrm{~m}$ (Setti et al. 2020). Because SARS-CoV-2 virus may remain infectious into aerosol droplets at least $3 \mathrm{~h}$ (Van Doremalen et al. 2020), wearing a mask in public places is strongly recommended.

The inconsistencies in the results of recent studies can be due to the limited numbers of samples, difference in the air sampling method, and RT-PCR analysis. The results and conditions of SARS-CoV-2 detection in the air samples in recent studies are presented in Table 3. As seen, the definite distance that SARS-CoV-2 can travel from the patients' beds is controversial.

In the present study, the variability in the SARS-CoV-2 contamination between hospital wards was interesting. It indicated that an effective management should be considered to prevent the spread of SARS-CoV-2 from contaminated to clean wards. However, WHO recommendations about ventilation rate in health care facilities, avoidance of air recirculation, and separation between COVID-19 patients and healthy subjects should be considered.

Overall, we suggest that avoiding busy crowds, social distancing, behavioral management, and wearing face masks can decline the spread of the SARS-CoV-2 virus in public buildings. The application of these measurements will greatly prevent the transmission of the virus. Finally, airborne transmission potential of SARS-CoV-2 needs more and more evidences.

There are some limitations in our study which should be addressed. First, the positive RT-PCR results did not indicate a viable virus in the samples. Therefore, in a conservative manner, we just stated that the SARS-CoV-2 RNA was present in the indoor air of the hospital. Second, the difficulty in the detection of low levels of SARS-CoV-2 in the air samples that needs to enhance virus culture techniques.

\section{Concentration and types of bioaerosols}

In the present study, 13 bacterial species and 9 fungal genera were detected in the air of the surveyed wards. It was found that Staphylococcus epidermidis was the most frequently isolated bacteria from the air of different hospital wards, followed by Klebsiella and Pseudomonas. Also, our results revealed that only Pseudomonas spp. and Staphylococcus epidermidis were detected in the ICU ward. The study showed that the bacteria found in the indoor air samples were opportunistic pathogens that are important causes of nosocomial infections. The main sources of bacteria in the hospital wards are from the staff, visitors, and patient activity (respiration, coughing, and sneezing), ward dust, and poor ventilation system (Frias-De Leon et al. 2016; Saadoun et al. 2008).

According to the results, the fungal bioaerosol concentration in the ICU was higher than the other wards. Previous studies have shown that the most common fungal bioaerosols in various hospital wards were Penicillium spp., Cladosporium spp., and Aspergillus (Dehghani et al. 2018; Kim et al. 2010). Cladosporium spp. is responsible for many fungal infections in the hospital. Several factors affect indoor concentration of fungal airborne such as sampling season, temperature, relative humidity, ventilation system, type of admitted patients, building materials, and outdoor fungal load (Abbasi and Samaei 2020). The results of study showed that the concentration of fungal bioaerosols in outdoor samples were higher than that in the hospital wards. Moreover, it is worth to mention that all the fungi species detected in outdoor samples were also found in the indoor ones, but some bacteria species like Staphylococcus epidermidis, Acinetobacter, Pseudomonas, Enterobacter aerogenes, Proteus, Staphylococcus aureus, Micrococcus, Neisseria, and Streptococcus were just detected in the indoor samples. Likewise, some fungal species like Scopulariopsis, Mycelium, and Mucor were only found in indoor samples. Therefore, it seems that some bacterial and fungal species present in the indoor environment of the hospital were probably originated from ambient air due to some outdoor activities. Sautour et al. (2009) and Mirhoseini et al. (2020) studies have confirmed this result. However, some other species were stemmed from the indoor environment.

Overall, in this study, airborne bioaerosol concentration in the ICU and respiratory patients' clinic was higher than the other wards. The high concentration of airborne bacterial and fungal bioaerosols could be considered as an important risk factor for COVID-19 patients with severe acute respiratory syndrome that admitted to these wards. Due to the fact that the number of people admitted to the respiratory patients clinics has increased during the COVID-19 pandemic, they can be affected by microbial load in this ward.

On the other word, long-term inhalation of high bacterial concentration may have adverse effects on human health, especially for sensitive individuals (Wu et al. 2020) like COVID-19 patients.

In addition, because of the significant association $(p<0.05)$ between bacteria levels and the virus presence in our study, 
Table 3 The results and conditions of SARS-CoV-2 detection in air samples in recent studies

\begin{tabular}{|c|c|c|c|c|c|c|c|c|}
\hline Study & Country & $\begin{array}{l}\text { \# of } \\
\text { samples }\end{array}$ & $\begin{array}{l}\# \text { or } \% \\
\text { of } \\
\text { positive } \\
\text { samples }\end{array}$ & $\begin{array}{l}\text { Distance from patients' } \\
\text { beds }(\mathrm{m})\end{array}$ & Sampler & $\begin{array}{l}\text { Culture } \\
\text { medium }\end{array}$ & $\begin{array}{l}\text { Sampling } \\
\text { time }\end{array}$ & Hospital ward \\
\hline $\begin{array}{l}\text { Faridi et al. } \\
\quad(2020)\end{array}$ & Iran & 10 & 0 & 2 to 5 & Impinger & DMEM & $1 \mathrm{~h}$ & ICU \\
\hline $\begin{array}{l}\text { Kenarkoohi } \\
\text { et al. } \\
(2020)\end{array}$ & Iran & 14 & 2 & - & Impinger & DMEM & $3 \mathrm{~h}$ & $\begin{array}{l}\text { ICU, Laboratory ward, CT scan, } \\
\text { Radiology, Men and Woman } \\
\text { internal ward, Emergency ward, } \\
\text { ICU and Hospital entrance hall }\end{array}$ \\
\hline $\begin{array}{l}\text { Ong et al. } \\
(2020)\end{array}$ & Singapore & 3 & 2 & - & $\begin{array}{l}\text { 37-mm filter } \\
\text { cassettes and } \\
0.3-\mu \mathrm{m} \text { PTFE } \\
\text { filters }\end{array}$ & - & $4 \mathrm{~h}$ & Infection isolation rooms \\
\hline $\begin{array}{l}\text { Guo et al. } \\
(2020)\end{array}$ & China & 40 & 14 & 4 & $\begin{array}{l}\text { SASS } 2300 \text { Wetted } \\
\text { Wall Cyclone } \\
\text { Sampler }\end{array}$ & - & $30 \mathrm{~min}$ & ICU, general COVID-19 ward \\
\hline $\begin{array}{l}\text { Chia et al. } \\
\text { (2020) }\end{array}$ & Singapore & - & $66.7 \%$ & - & $\begin{array}{l}\text { Cyclone Bioaerosol } \\
\text { Sampler }\end{array}$ & - & $4 \mathrm{~h}$ & ICU, General ward \\
\hline $\begin{array}{l}\text { Santarpia } \\
\quad \text { et al. } \\
\text { (2020) }\end{array}$ & $\begin{array}{l}\text { United } \\
\text { Stated }\end{array}$ & 11 & $63.2 \%$ & Greater than $2 \mathrm{~m}$ & $\begin{array}{l}\text { Sartorius Airport } \\
\text { MD8 air sampler, } \\
80 \mathrm{~mm} \text { gelatin } \\
\text { filter }\end{array}$ & - & $15 \mathrm{~min}$ & Patient rooms, hallways \\
\hline $\begin{array}{l}\text { Razzini } \\
\text { et al. } \\
\text { (2020) }\end{array}$ & Italy & 5 & 5 & - & $\begin{array}{l}\text { MD8 Airport } \\
\text { Portable Air } \\
\text { Sampler with } \\
\text { gelatine } \\
\text { Membrane } \\
\text { Filters }\end{array}$ & - & $40 \mathrm{~min}$ & $\begin{array}{l}\text { Corridor for patients,ICU, dressing } \\
\text { and undressing room }\end{array}$ \\
\hline $\begin{array}{r}\text { Tan et al. } \\
(2020)\end{array}$ & China & 29 & 1 & $1 \mathrm{~m}$ of the patient's head & Membrane & VTM & $1 \mathrm{~h}$ & $\begin{array}{l}\text { Patient rooms, corridor outside the } \\
\text { patient rooms, nearby nursing } \\
\text { stations }\end{array}$ \\
\hline $\begin{array}{r}\text { Ahn et al. } \\
(2020)\end{array}$ & Korea & 9 & 0 & $1 \mathrm{~m}$ of the patient's bed & SKC BioSampler & PBS & $20 \mathrm{~min}$ & Patient rooms \\
\hline $\begin{array}{l}\text { Nissen et al. } \\
\quad(2020)\end{array}$ & Sweden & 38 & 11 & Ventilation exhaust filters & Petri dishes & DMEM & $24 \mathrm{~h}$ & $\begin{array}{l}\text { Ward rooms and exits, directly prior to } \\
\text { exhaust filters }\end{array}$ \\
\hline $\begin{array}{l}\text { Lei et al. } \\
\quad(2020)\end{array}$ & China & 218 & 1 & $1 \mathrm{~m}$ of the patient's head & Two-stage cyclonic & - & $4 \mathrm{~h}$ & ICU and isolation ward \\
\hline $\begin{array}{l}\text { Lednicky } \\
\text { et al. } \\
\text { (2020) }\end{array}$ & USA & 22 & 12 & $\begin{array}{l}2 \text { to } 4.8 \mathrm{~m} \text { away from the } \\
\text { patients }\end{array}$ & $\begin{array}{l}\text { BioSpot-VIVAS } \\
\text { Sampler }\end{array}$ & - & $3 \mathrm{~h}$ & Ward rooms \\
\hline This study & Iran & 45 & 6 & 2,5 & Impinger & VTM & $4 \mathrm{~h}$ & $\begin{array}{l}\text { Infectious } 1 \text { and } 2 \text { wards, ICU, } \\
\text { Pediatric ward, CT scan, } \\
\text { Emergency ward, Laundry, } \\
\text { Respiratory patients clinic }\end{array}$ \\
\hline
\end{tabular}

DMEM Dulbecco's Modified Eagle's Medium, PTFE polytetrafluoroethylene, PBS phosphate-buffered saline

the presence of high concentrations of bacteria, especially opportunistic pathogens, can lead to secondary infections (Smith and Sweet 2002) and probably increase mortality rate in COVID-19 patients.

The significant correlation of airborne bacterial levels and SARS-CoV-2 in various wards of hospital implies that the bacterial contamination of indoor air can be considered as a surrogate for the presence of SARS-CoV-2. In this regard, monitoring the microbial quality of indoor air in hospitals admitting COVID-19 patients is an important and necessary factor for controlling the nosocomial infections and respiratory diseases and to somewhat guarantee the absence of SARS-CoV-2 in air. Increasing the ventilation rate (mechanical or natural systems), periodic monitoring of the microbial quality in the indoor air of hospitals, controlling the temperature and humidity, and performing regular disinfection, can reduce the microbial population in the indoor air of health care facilities.

\section{Conclusion}

The present study provides the first report on the bacterial and fungal diversity in indoor air of hospital during COVID-19 
pandemic. In this regard, we detected 6 positive indoor air samples, which were collected from nine different wards of the hospital. Five positive samples were found at a distance of $2 \mathrm{~m}$ from the COVID-19 patient's bed. Moreover, none of the air samples were positive in the distance of $5 \mathrm{~m}$ from the COVID-19 patients' bed. It seems that the safe physical distance from COVID-19 patients are more than $2 \mathrm{~m}$. Our findings showed that the fungal concentrations were higher than the bacterial concentration in indoor air of the hospital. The most isolated bacterial bioaerosols were Staphylococcus spp., Bacillus spp., and Pseudomonas spp. in all samples. In addition, the main fungal species detected in the air of COVID-19 patients' rooms were Cladosporium spp., Alternaria spp., and Yeast spp. Also, the significant correlation $(p<0.05)$ was found between airborne bacterial concentration and SARS$\mathrm{CoV}-2$. Overall, this study provided an additional evidence on the presence of SARS-CoV-2 in indoor air of hospitals admitting COVID-19 patient, especially near the patients' bed. Moreover, it was revealed that the control of microbial quality of indoor air in such hospitals is crucial. The results of this study imply that the contact with bioaerosols generated through COVID-19 patients, health care workers, and visitors' exhalation in the hospital wards may pose serious health threat especially for susceptible individuals. Hence, it is essential to supply fresh and sterilized air in various hospital wards.

\begin{abstract}
Abbreviations WHO, World Health Organization; ICU, Intensive care unit; CT, Computed tomography; PPE, Personal protective equipment; VTM, Viral transport medium; TSA, Tryptic soy agar; SDA, Sabouraud dextrose agar; CDC, Centers for Disease Control and Prevention; RTPCR, Real-time reverse transcription polymerase chain reaction; RDRP, RNA-dependent RNA polymerase; NP, Nucleocapsid protein; OF, Oxidation/fermentation
\end{abstract}

Supplementary Information The online version contains supplementary material available at https://doi.org/10.1007/s11356-021-13628-9.

Acknowledgements We are grateful to the financial support (Grant Number: 3338) of the research deputy of Shahrekord University of Medical Sciences, Iran. Also, we thank the staff of Hajar Hospital Complex and the Department of Virology, Shahrekord University of Medical Sciences.

Availability of data and materials Not applicable.

Author contribution Sara Hemati: project administration, supervision, performed the experiments and writing-original draft preparation, review and editing. Gholam Reza Mobini: methodology, validation, formal analysis. Mohsen Heidari: writing-original draft preparation, review and editing. Fereidoun Rahmani: writing-review and editing, data curation. Akbar Soleymani Babadi: writing-review and editing, data curation. Marzieh Farhadkhani: writing-original draft preparation, review and editing. Heshmatollah Nourmoradi: writing-original draft preparation, review, and editing. Ahmad Raeisi: writing-review and editing, data curation. Ali Ahmadi: data analysis, writing-original draft preparation. Abbas Khodabakhshi: writing-review and editing. Mehraban Sadeghi: writing-review and editing. Milad Bagheri: taking the air samples and methodology. Majid Validi: methodology, validation, formal analysis. Simin Taghipour: methodology, validation, formal analysis. Fazel Mohammadi-Moghadam: conceptualization, methodology, validation, formal analysis, resources, writing-original draft, review and editing, project administration, supervision, funding acquisition. All authors have approved the final version of the manuscript.

Funding This work was supported by research deputy of Shahrekord University of Medical Sciences [Grant Number: 3338].

\section{Declarations}

Ethical approval The current study was approved by the Medical Ethics Committee of Shahrekord University of Medical Sciences (IR.SKUMS.Rec.1399.082).

Consent to participate Not applicable.

Consent for publication

Not applicable.

Conflict of interests The authors declare no competing interests.

\section{References}

Abbasi F, Samaei MR (2020) The effect of temperature on airborne filamentous fungi in the indoor and outdoor space of a hospital. Environ. Sci Pollut Res 26(17):16868-16876

Ahn JY, An S, Sohn Y, Cho Y, Hyun JH, Baek YJ, Kim MH, Jeong SJ, Kim JH, Ku NS, Yeom JS, Smith DM, Lee H, Yong D, Lee YJ, Kim JW, Kim HR, Hwang J, Choi JY (2020) Environmental contamination in the isolation rooms of COVID-19 patients with severe pneumonia requiring mechanical ventilation or high-flow oxygen therapy. J Hosp Infect 106(3):570-576

Bourouiba L (2020) Turbulent gas clouds and respiratory pathogen emissions: potential implications for reducing transmission of COVID19. Jama 323(18):1837-1838

Buonanno G, Stabile L, Morawska L (2020) Estimation of airborne viral emission: quanta emission rate of SARS-CoV-2 for infection risk assessment. Environ Int 141:105794

(CDC), C. F. D. C. A. P (2020) Cleaning and disinfection for households. Interim Recommendations for U.S. Households With Suspected or Confirmed Coronavirus Disease 2019 (COVID-19). National Center for Immunization and Respiratory Diseases (NCIRD), Division of Viral Diseases May 13

Cheung JC-H, Ho LT, Cheng JV, Cham EYK, Lam KN (2020) Staff safety during emergency airway management for COVID-19 in Hong Kong. Lancet Respir Med 8(4):e19

Chia PY, Coleman KK, Tan YK, Ong SWX, Gum M, Lau SK (2020) Detection of air and surface contamination by SARS-CoV-2 in hospital rooms of infected patients. Nat Commun 11(1):1-7

Dehghani M, Sorooshian A, Nazmara S, Baghani AN, Delikhoon M (2018) Concentration and type of bioaerosols before and after conventional disinfection and sterilization procedures inside hospital operating rooms. Ecotoxicol Environ Saf 164(1):277-282

Fabian M, Miller S, Reponen T, Hernandez M (2005) Ambient bioaerosol indices for indoor air quality assessments of flood reclamation. J Aerosol Sci 36(5):763-783

Faridi S, Niazi S, Sadeghi K, Naddafi K, Yavarian J, Shamsipour M, Jandaghi N.Z.S, Sadeghniiat K, Nabizadeh R, Yunesian M (2020) 
A field indoor air measurement of SARS-CoV-2 in the patient rooms of the largest hospital in Iran. Sci Total Environ 725: 138401

Forrester JD, Nassar AK, Maggio PM, Hawn MT (2020) Precautions for operating room team members during the COVID-19 pandemic. J Am Coll Surg 230(6):1098-1101

Frias-De Leon MG, Duarte-Escalante E, del Carmen C-EM, del Carmen J-MM, Acosta-Altamirano G, Moreno-Eutimio MA (2016) Diversity and characterization of airborne bacteria at two health institutions. Aerobiologia 32(2):187-198

Guo Z-D, Wang Z-Y, Zhang S-F, Li X, Li L, Li C, Cui Y, Fu R-B, Dong Y-Z, Chi X-Y, Zhang M-Y, Liu K, Cao C, Liu B, Zhang K, Gao YW, Lu B, Chen W (2020) Aerosol and surface distribution of severe acute respiratory syndrome coronavirus 2 in hospital wards, Wuhan, China. Emerg Infect Dis 26(7):3201

Hamad MTMH, Soliman MSS (2020) Application of Immobilized Aspergillus niger in Alginate for Decolourization of Congo Red Dye by Using Kinetics Studies. J Polym Environ 28(12):3164-3180

He P, Wu Y, Huang W, Wu X, Lv J, Liu P (2020) Characteristics of and variation in airborne ARGs among urban hospitals and adjacent urban and suburban communities: a metagenomic approach. Environ Int 139:105625

Holshue ML, DeBolt C, Lindquist S, Lofy KH, Wiesman J, Bruce H (2020) First case of 2019 novel coronavirus in the United States. N Engl J Med 382:92936

Jayaweera M, Perera H, Gunawardana B, Manatunge J (2020) Transmission of COVID-19 virus by droplets and aerosols: a critical review on the unresolved dichotomy. Environ Res 188:109819

Judson SD, Munster VJ (2019) Nosocomial transmission of emerging viruses via aerosol-generating medical procedures. Viruses 11(10): 940

Kenarkoohi A, Noorimotlagh Z, Falahi S, Amarloei A, Mirzaee SA, Pakzad I (2020) Hospital indoor air quality monitoring for the detection of SARS-CoV-2 (COVID-19) virus. Sci Total Environ 748: 141324

Kim KY, Kim YS, Kim D (2010) Distribution characteristics of airborne bacteria and fungi in the general hospitals of Korea. Ind Health 48(2):236-243

Lednicky JA, Lauzard M, Fan ZH, Jutla A, Tilly TB, Gangwar M et al (2020) Viable SARS-CoV-2 in the air of a hospital room with COVID-19 patients. Int J Infect Dis 100:476-482

Lee J, Yoo D, Ryu S, Ham S, Lee K, Yeo M, Min K, Yoon C (2019) Quantity, size distribution, and characteristics of cough-generated aerosol produced by patients with an upper respiratory tract infection. Aerosol Air Qual Res 19(4):840-853

Lei H, Ye F, Liu X, Huang Z, Ling S, Jiang Z et al (2020) SARS-CoV-2 environmental contamination associated with persistently infected COVID-19 patients. Influenza Other Respir Viruses 14(6):688-699

Mirhoseini SH, Didehdar M, Akbari M, Moradzadeh R, Jamshidi R, Torabi S (2020) Indoor exposure to airborne bacteria and fungi in sensitive wards of an academic pediatric hospital. Aerobiologia 36: 225-232

Morawska L, Cao J (2020) Airborne transmission of SARS-CoV-2: the world should face the reality. Environ Int 139:105730

Nissen K, Krambrich J, Akaberi D, Hoffman T, Ling J, Lundkvist A et al (2020) Long-distance airborne dispersal of SARS-CoV-2 in COVID-19 wards. Sci Rep 10(1):1-9

Ong SWX, Tan YK, Chia PY, Lee TH, Ng OT, Wong MSY (2020) Air, surface environmental, and personal protective equipment contamination by severe acute respiratory syndrome coronavirus 2 (SARSCoV-2) from a symptomatic patient. Jama 323(16):1610-1612

Razzini K, Castrica M, Menchetti L, Maggi L, Negroni L, Orfeo NV (2020) SARS-CoV-2 RNA detection in the air and on surfaces in the COVID-19 ward of a hospital in Milan, Italy. Sci Total Environ $742: 140540$
Repici A, MasellZ R, Colombo M, Gabbiadini R, Spadaccini M, Anderloni A (2020) Coronavirus (COVID-19) outbreak: what the department of endoscopy should know. Gastrointes Endosc 92:192197

Ricco M, Ranzieri S, Balzarini F, Bragazzi NL, Corradi M (2020) SARSCoV-2 infection and air pollutants: correlation or causation? Sci Total Environ 734:139489

Saadoun I, Al Tayyar IA, Elnasser Z (2008) Concentrations of airborne fungal contaminations in the medical surgery operation theaters (OT) of different hospitals in northern Jordan. Jordan J Biol Sci. 1: 181-184

Santarpia JL, Rivera DN, Herrera V, Morwitzer MJ, Creager H, Santarpia GW (2020) Transmission potential of SARS-CoV-2 in viral shedding observed at the University of Nebraska Medical Center. MedRxIV. 1-12

Sautour M, Sixt N, Dalle F, L'Ollivier C, Fourquenet V, Calinon C, Paul K, Valvin S, Maurel A, Aho S, Couillault G, Cachia C, Vagner O, Cuisenier B, Caillot D, Bonnin A (2009) Profiles and seasonal distribution of airborne fungi in indoor and outdoor environments at a French hospital. Sci Total Environ 407(12):3766-3771

Setti L, Passarini F, De Gennaro G, Barbieri P, Perrone MG, Borelli M (2020) Airborne transmission route of COVID-19: why 2 meters/6 feet of inter-personal distance could not Be enough. Int J Environ Res Public Health 17:2932

Smith H, Sweet C (2002) Cooperation between viral and bacterial pathogens in causing human respiratory disease. Polymicrobial Diseases ASM Press

Soma M, Jacobson I, Brewer J, Blondin A, Davidson G, Singham S (2020) Operative team checklist for aerosol generating procedures to minimise exposure of healthcare workers to SARS-CoV-2. Int J Pediatr Otorhinolaryngol 134:110075

Tan L, Ma B, Lai X, Han L, Cao P, Zhang J (2020) Air and surface contamination by SARS-CoV-2 virus in a tertiary hospital in Wuhan, China. Int J Infect Dis 99:3-7

Van Doremalen N, Bushmaker T, Morris DH, Holbrook MG, Gamble A, Williamson BN (2020) Aerosol and surface stability of SARS-CoV2 as compared with SARS-CoV-1. N Engl J Med 382:1564-1567

Wang D, Zhou M, Nie X, Qiu W, Yang M, Wang X (2020) Epidemiological characteristics and transmission model of Corona Virus Disease 2019 in China. J of Infec 80:e25-e27

(WHO), W. H. O (2020) Coronavirus Disease (COVID-19) Situation Report- 205, Data as Received by WHO From National Authorities by 10:00 CEST, 12 August 2020

Wong S-Y, Kwong R-S, Wu TC, Chan J, Chu M, Lee S (2020) Risk of nosocomial transmission of coronavirus disease 2019: an experience in a general ward setting in Hong Kong. J Hosp Infect 105:119-125

Wu B, Qi C, Wang L, Yang W, Zhou D, Wang M (2020) Detection of microbial aerosols in hospital wards and molecular identification and dissemination of drug resistance of Escherichia coli. Environ Int 137:105479

Yao M, Zhang L, Ma J, Zhou L (2020) On airborne transmission and control of SARS-Cov-2. Sci Total Environ 731:139178

Zhong X, Qi J, Li H, Dong L, Gao D (2016) Seasonal distribution of microbial activity in bioaerosols in the outdoor environment of the Qingdao coastal region. Atmos Environ 140:506-513

Zumla A, Niederman MS (2020) The explosive epidemic outbreak of novel coronavirus disease 2019 (COVID-19) and the persistent threat of respiratory tract infectious diseases to global health security. Curr Opin Pulm Med 26:1-3

Publisher's note Springer Nature remains neutral with regard to jurisdictional claims in published maps and institutional affiliations. 


\section{Affiliations}

\section{Sara Hemati ${ }^{1}$ - Gholam Reza Mobini ${ }^{2}$ - Mohsen Heidari ${ }^{3}$ - Fereidoun Rahmani ${ }^{4}$ - Akbar Soleymani Babadi ${ }^{5}$. Marzieh Farhadkhani ${ }^{6} \cdot$ Heshmatollah Nourmoradi $^{7,8} \cdot$ Ahmad Raeisi $^{9} \cdot$ Ali Ahmadi $^{10}$ - Abbas Khodabakhshi ${ }^{1}$. Mehraban Sadeghi ${ }^{1} \cdot$ Milad Bagheri $^{1} \cdot$ Majid Validi $^{11} \cdot$ Simin Taghipour ${ }^{12} \cdot$ Fazel Mohammadi-Moghadam $^{1}$}

Sara Hemati

hemati.sara88@yahoo.com

Gholam Reza Mobini

gmobini52@gmail.com

Mohsen Heidari

moheidari@modares.ac.ir

Fereidoun Rahmani

darman@skums.ac.ir

Akbar Soleymani Babadi

dr.akbarsoleymani@yahoo.com

Marzieh Farhadkhani

m_farhadkhani@yahoo.com

Heshmatollah Nourmoradi

ilam_nourmoradi@yahoo.com

\author{
Ahmad Raeisi \\ draraeisi88@yahoo.com \\ Ali Ahmadi \\ aliahmadi2007@gmail.com \\ Abbas Khodabakhshi \\ khodabakhshi16@gmail.com \\ Mehraban Sadeghi \\ Sadeghi@skums.ac.ir \\ Milad Bagheri \\ milad.bagheri.farsani1371@gmail.com \\ Majid Validi \\ validi543@gmail.com \\ Simin Taghipour \\ simintaghipoor@yahoo.com
}

7 Biotechnology and Medicinal Plant Research Center, Ilam University of Medical Sciences, Ilam, Iran

8 Department of Environmental Health Engineering, School of Health, Ilam University of Medical Sciences, Ilam, Iran

9 Department of Internal Medicine, School of Medicine, Shahrekord University of Medical Sciences, Shahrekord, Iran

10 Department of Epidemiology, Modeling in Health Research Center, Shahrekord University of Medical Sciences, Shahrekord, Iran

11 Department of Medical Bacteriology, School of Allied Medical Sciences, Shahrekord University of Medical Sciences, Shahrekord, Iran

12 Department of Medical Mycology and Parasitology, School of Medicine, Shahrekord University of Medical Sciences, Shahrekord, Iran 